\title{
Effect of the anti-diabetic drug metformin in hepatocellular carcinoma in vitro and in vivo
}

\author{
HISAAKI MIYOSHI ${ }^{1}$, KIYOHITO KATO ${ }^{1}$, HISAKAZU IWAMA ${ }^{2}$, EMIKO MAEDA ${ }^{1}$, \\ TEPPEI SAKAMOTO ${ }^{1}$, KOJI FUJITA ${ }^{1}$, YUKA TOYOTA ${ }^{1}$, JOJI TANI ${ }^{1}$, TAKAKO NOMURA ${ }^{1}$, \\ SHIMA MIMURA $^{1}$, MITSUYOSHI KOBAYASHI ${ }^{1}$, ASAHIRO MORISHITA ${ }^{1}$, HIDEKI KOBARA ${ }^{1}$, \\ HIROHITO MORI $^{1}$, HIROHITO YONEYAMA ${ }^{1}$, AKIHIRO DEGUCHI ${ }^{1}$, TAKASHI HIMOTO ${ }^{1}$, \\ KAZUTAKA KUROKOHCHI $^{1}$, KEIICHI OKANO ${ }^{3}$, YASUYUKI SUZUKI ${ }^{3}$, \\ KOJI MURAO ${ }^{4}$ and TSUTOMU MASAKI ${ }^{1}$ \\ ${ }^{1}$ Department of Gastroenterology and Neurology, ${ }^{2}$ Life Science Research Center, \\ Departments of ${ }^{3}$ Gastroenterological Surgery and ${ }^{4}$ Laboratory Medicine, \\ Faculty of Medicine, Kagawa University, Kagawa, Japan
}

Received October 19, 2013; Accepted April 7, 2014

DOI: 10.3892/ijo.2014.2419

\begin{abstract}
Metformin is a commonly used oral antihyperglycemic agent of the biguanide family. Recent studies suggest that metformin may reduce cancer risk and improve prognosis. However, the antitumor mechanism of metformin in several types of cancers, including hepatocellular carcinoma (HCC), has not been elucidated. The goal of the present study was to evaluate the effects of metformin on HCC cell proliferation in vitro and in vivo, and to study microRNAs (miRNAs) associated with the antitumor effect of metformin in vitro. We used the cell lines Alex, HLE and Huh7, and normal hepatocytes to study the effects of metformin on human HCC cells. In an in vivo study, athymic nude mice bearing xenograft tumors were treated with metformin or left untreated. Tumor growth was recorded after 4 weeks, and the expression of cell cycle-related proteins was determined. Metformin inhibited the proliferation of Alex, HLE and Huh7 cells in vitro and in vivo. Metformin blocked the cell cycle in G0/G1 in vitro and in vivo. This blockade was accompanied by a strong decrease of G1 cyclins, especially cyclin D1, cyclin E and cyclin-dependent kinase 4 (Cdk4). In addition, microRNA (miRNA) expression was markedly
\end{abstract}

Correspondence to: Professor Tsutomu Masaki, Department of Gastroenterology and Neurology, Faculty of Medicine, Kagawa University, 1750-1 Ikenobe, Miki-cho, Kita-gun, Kagawa 761-0793, Japan

E-mail: tmasaki@med.kagawa-u.ac.jp

Abbreviations: miRNA, microRNA; Cdk, cyclin-dependent kinase; PBS, phosphate-buffered saline; HCC, hepatocellular carcinoma

Key words: metformin, hepatocellular carcinoma, microRNA, Huh7 altered by the treatment with metformin in vitro and in vivo. In addition, various miRNAs induced by metformin also may contribute to the suppression of tumor growth. Our results demonstrate that metformin inhibits the growth of HCC, possibly by inducing G1 cell cycle arrest through the alteration of microRNAs.

\section{Introduction}

Hepatocellular carcinoma (HCC) is one of the most common and frequently occurring tumors worldwide (1). Although the clinical diagnosis and management of early-stage HCC have improved significantly, HCC prognosis is still extremely poor (2). Furthermore, advanced HCC is a highly aggressive tumor with poor or no response to common therapies. Thus, there is a strong demand for new curative approaches to advanced $\mathrm{HCC}$.

Metformin is an oral biguanide drug introduced into clinical practice in the 1950s for the treatment of type 2 diabetes (3). It lowers hyperglycemia by inhibiting hepatic glucose production. According to a recent gastroenterological study, metformin has significant effects on tumorigenesis (4). For instance, it has been reported that patients with type 2 diabetes who are prescribed metformin have a lower risk of pancreatic cancer compared to patients who do not take metformin (5). In basic investigations, metformin was shown to inhibit the proliferation of various human cancer cell types, such as those of the prostate (6), breast (7), colon $(8,9)$, stomach (10), esophagus (11) and HCC (12). However, the mechanism underlying the growth suppression of various cancers, including $\mathrm{HCC}$, by metformin remains relatively unknown.

The relatively recent investigation into miRNAs has identified a new layer of gene regulation mechanisms. It has become apparent that aberrant miRNA expression is a common feature of various human malignancies. In terms of the relationship between miRNAs and HCC, many studies 
have shown that specific miRNAs are expressed aberrantly in malignant HCC cells or tissues compared to non-malignant hepatocytes and tissues (13-15). These previous studies have also shown that the modulation of non-coding RNAs, specifically miRNAs, may act to modulate HCC formation. However, although miRNAs are becoming increasingly recognized as regulatory molecules in $\mathrm{HCC}$, their involvement in the responses to environmental changes, such as exposure to drugs, remains unknown.

Here we show that metformin is effective for the treatment of $\mathrm{HCC}$, and have also studied the expression of cell cycle-related molecules, tyrosine kinases of receptor type and angiogenesis molecules to explore the mechanism underlying the antitumor effect of metformin. In addition, we have identified miRNAs associated with the antitumor effect of metformin.

\section{Materials and methods}

Chemicals. Metformin (1,1-dimethylbiguanide monohydrochloride) was purchased from Dainippon Sumitomo Pharma (Tokyo, Japan). A Cell Counting Kit (CCK-8) was purchased from Dojindo Laboratories (Kumamoto, Japan), and all other chemicals were obtained from Sigma Chemical (Tokyo, Japan).

Antibodies. In this study, the following antibodies were used: anti- $\beta$-actin monoclonal antibody (Sigma-Aldrich, St. Louis, MO; A5441, used at 1:3,000), cyclin D1 (Thermo Fisher Scientific, Waltham, MA; RB-9041, used at 1:1,000), cyclin E (BD Biosciences, Franklin Lakes, NJ; used at 1:1,000), Cdk6 (Santa Cruz Biotechnology, Santa Cruz, CA; sc-177, used at 1:1,000), Cdk4 (Cell Signaling Technology, Danvers, MA; \#2906, used at 1:1,000), Cdk2 (Santa Cruz Biotechnology, sc-163, used at 1:2,000), and secondary horseradish peroxidase-linked anti-mouse and anti-rabbit IgG antibodies (GE Healthcare UK, Buckinghamshire, UK; used at 1:2,000).

Cell lines and culture. The human HCC cell lines Alex, HLE and Huh7 were obtained from the Japanese Cancer Research Resources Bank (Tokyo, Japan). Cells of a normal human liver cell line, Hc-Cells, were obtained from DS Pharma Biomedical (Osaka, Japan). The human HCC cells were grown in RPMI-1640 (Gibco Invitrogen, Carlsbad, CA, USA) and human normal liver cells were grown in a CS-C Complete Medium Kit R (DS Pharma Biomedical, Osaka, Japan). Both media contained 10\% fetal bovine serum (533-69545; Wako, Osaka, Japan) and penicillin-streptomycin (100 mg/l; Invitrogen, Tokyo, Japan).

Cell proliferation assay. Cell proliferation assays were performed using the Alex, HLE, and Huh7 cells according to the manufacturer's instructions. Cells from each line $\left(1 \times 10^{4}\right)$ were seeded into a well of a 96 -well plate and cultured in $100 \mu \mathrm{l}$ of RPMI-1640 supplemented with 10\% FBS. After $24 \mathrm{~h}$ seeding cells were treated by addition of 1 or $5 \mathrm{mM}$ metformin into the culture medium or were left untreated. At the indicated time points, the medium was exchanged for $110 \mu \mathrm{l}$ of RPMI-1640 with the cell lines reagent (10 $\mu \mathrm{l} \mathrm{CCK}-8$ and $100 \mu 1$ RPMI-1640), and the cells were incubated for $2 \mathrm{~h}$. The absorbance was measured for each well at a wavelength of $450 \mathrm{~nm}$ using an auto-microplate reader.
Cell lysate and tissue lysate. The cell lysate assay was performed according to the methods described in our previous reports (16-18). All steps were carried out at $4^{\circ} \mathrm{C}$. Protein concentrations were measured using a dye-binding protein assay based on the Bradford method (19).

Gel electrophoresis and western blot analysis. Samples were electrophoresed using $10 \%$ sodium dodecyl sulfatepolyacrylamide gels (SDS-PAGE) (18), and the proteins were transferred to nitrocellulose membranes. The membranes were incubated with primary antibodies after blocking. Then, the membranes were incubated with horseradish peroxidaseconjugated secondary antibodies (20). The immunoreactive proteins were visualized with an enhanced chemiluminescence detection system (Perkin-Elmer Co., Waltham, MA) on X-ray film.

Flow cytometry analysis. To evaluate the mechanism of growth inhibition by metformin, the cell cycle profile was analyzed after treatment with metformin. Huh7 cells (1.0x $10^{6}$ cells in a 6 -well plate dish) were treated with $10 \mathrm{mM}$ metformin or without metformin for $24-72 \mathrm{~h}$. After treatment, the cells were harvested and fixed in $80 \%$ ethanol. The fixed cells were washed with PBS and then stored at $-20^{\circ} \mathrm{C}$ until flow cytometric analysis was performed. On the day of analysis, cells were washed and centrifuged using cold PBS, suspended in $100 \mu \mathrm{l}$ PBS and $10 \mu \mathrm{l}$ RNase A solution $(250 \mu \mathrm{g} / \mathrm{ml})$ and incubated for $30 \mathrm{~min}$ at $37^{\circ} \mathrm{C}$. Then, $110 \mu \mathrm{l}$ propidium iodide (PI) stain $(100 \mu \mathrm{g} / \mathrm{ml})$ was added to each tube, and the tubes were incubated at $4^{\circ} \mathrm{C}$ for at least $30 \mathrm{~min}$ prior to analysis.

Flow cytometric analysis was performed using a Cytomics FC 500 flow cytometer (Beckman Coulter, Brea, CA) appointed with an argon laser $(488 \mathrm{~nm})$. The percentages of cells in different phases of the cell cycle were analyzed by using FlowJo software (Tree Star, Ashland, OR). All experiments were performed in triplicate to assess for consistency of response.

Xenograft model analysis. Animal experiments were performed according to the guidelines of the Committee on Experimental Animals of Kagawa University and use of animals by National Cancer Research Institute (NCRI) (21). We purchased 30 male athymic mice (BALB/c-nu/nu; 8 weeks old; 20-25 g) from Japan SLC (Hamamatsu, Japan). The animals were maintained under specific pathogen-free conditions using a laminar airflow rack and had continuous free access to sterilized food (gamma-ray-irradiated food, CL-2; Clea Japan, Tokyo, Japan) and autoclaved water. Each mouse was subcutaneously inoculated with Huh7 cells $\left(5 \times 10^{6}\right.$ cells/animal $)$ in the flank region. After the xenografts were identifiable as a mass of more than $6 \mathrm{~mm}$ in maximal diameter in all recipients, the animals were randomly assigned to three groups. The metformin-treated group was injected 5 times a week intraperitoneally (i.p.) at $1 \mathrm{mg} /$ body or $2 \mathrm{mg} /$ body per day for 2 weeks. The control group was administered only PBS $(n=10)$ for 2 weeks. After the initiation of the metformin administration, the tumor growth was monitored by the same investigators (H.M. and T.M.), and the tumorigenesis of HCC was monitored every 
day. Tumor size was measured weekly by measuring the two greatest perpendicular tumor dimensions. To examine the significance of the differences between growth curves in this study, all the measurements of tumor volume for each growth curve from the start of the treatment to the end, typically about 30 observations, were analyzed by one-way analysis of variance (ANOVA). The tumor volume was calculated as follows: tumor volume $\left(\mathrm{mm}^{3}\right)=$ tumor length $(\mathrm{mm}) \mathrm{x}$ tumor width $\left.(\mathrm{mm})^{2}\right] / 2(22)$. All animals were sacrificed on day 14 after treatment. All animals were alive during the observation.

Antibody arrays of phosphorylated receptor tyrosine kinase ( $p$-RTK). The RayBio ${ }^{\mathrm{TM}}$ Human Phospho Array Kit (cat. no. ARY 001) was purchased from RayBiotech Inc. (Norcross, GA). The assay for the p-RTK array was performed according to the manufacturer's instructions. Briefly, p-RTK array membranes were blocked with 5\% BSA/TBS (0.01 M Tris-HCl, $\mathrm{pH} 7.6)$ for $1 \mathrm{~h}$. The membranes were then incubated with $2 \mathrm{ml}$ of lysate prepared from cell lines or tumorous tissues after normalization with equal amounts of protein. After extensive washing with TBS including $0.1 \%$ v/v Tween-20 (3 washings of $10 \mathrm{~min}$ each), and TBS alone ( 2 washings of $10 \mathrm{~min}$ each) to remove unbound materials, the membranes were incubated with anti-phospho-tyrosine-HRP antibody for $2 \mathrm{~h}$ at room temperature. The unbound HRP antibody was washed out with TBS including $0.1 \%$ Tween-20. Finally, each array membrane was exposed to X-ray film using a chemiluminescence detection system (Perkin-Elmer Co.).

Antibody array for angiogenesis. To assess whether molecules important in angiogenesis are regulated by the antitumor effect of metformin, the RayBio Human Angiogenesis Antibody Array (RayBiotech Inc.) was used according to the protocol. This method is a dot-blot-based assay which enables detection and comparison of 19 different angiogenesis-specific cytokines. Briefly, angiogenesis protein array membranes were blocked with 5\% BSA/TBS (0.01 M Tris-HCl, pH 7.6) for $1 \mathrm{~h}$. The membranes were then incubated with $2 \mathrm{ml}$ of lysate prepared from tumor tissues after normalization with equal amounts of protein. After extensive washing with TBS including $0.1 \% \mathrm{v} / \mathrm{v}$ Tween-20 (3 washings of $5 \mathrm{~min}$ each) to remove unbound materials, the membranes were incubated with HRP angiogenesis antibody for $2 \mathrm{~h}$ at room temperature. Unbound HRP antibody was washed out with TBS including $0.1 \%$ Tween-20. Finally, each array membrane was exposed to X-ray film using a chemiluminescence detection system (Perkin-Elmer Co.).

Densitometric analysis. The densitometric densities of p-EGFR and p-IGF-1R in the cell lines and p-EGFR, Mer and angiogenin in tumorous tissue were visualized in black and white, respectively. The densities of p-EGFR, p-IGF-1R and Mer obtained from the membrane array were analyzed by means of a Kodak Image Station (Kodak, Tokyo, Japan).

Analysis of miRNA microarray. The samples of cancer cell lines were processed for total RNA extraction with an miRNeasy mini kit (Qiagen, Hilden, Germany) according to the manufacturer's instructions. RNA samples typically showed A260/280 ratios of between 1.9 and 2.1, as determined using an Agilent 2100 Bioanalyzer (Agilent Technologies, Santa Clara, CA). After RNA measurement with an RNA 6000 Nano kit (Agilent Technologies), the samples were labeled using a miRCURY Hy3/Hy5 Power labeling kit and were hybridized on a human miRNA Oligo chip (v.14.0; Toray Industries, Tokyo, Japan). Scanning was performed with the 3D-Gene Scanner 3000 (Toray Industries). 3D-Gene extraction version 1.2 software (Toray Industries) was used to read the raw intensity of the image. To determine the change in miRNA expression between metformin-treated and control samples, the raw data were analyzed via GeneSpringGX v 10.0 (Agilent Technologies). Samples were first normalized relative to 28sRNA and baseline corrected to the median of all samples. Replicate data were consolidated into two groups: those from metformintreated animals and those from control animals, and were organized by using the hierarchical clustering and analysis of variance (ANOVA) functions in the GeneSpring software. Hierarchical clustering was done by using the clustering function (condition tree) and Euclidean correlation as a distance metric. Two-way ANOVA analysis and asymptotic p-value computation without any error correction on the samples were performed to search for the miRNAs that varied most prominently across the different groups. The p-value cutoff was set to 0.05 . Only changes $>50 \%$ on at least one of the time points for each sample were considered significant. All the analyzed data were scaled by global normalization. The statistical significance of differentially expressed miRNAs was analyzed by Student's t-test. All our micoroarray data in this study were submited as a complete data set to the NCBI Gene Expression Omnibus (GEO), no. 44204 (http://www.ncbi.nlm.nih.gov/geo/query/acc.cgi? token=ljglzioeieoqijc\&acc=GSE44204).

\section{Results}

Metformin inhibits the proliferation of human HCC cell lines. To evaluate the effect of the cell growth of metformin on human HCC cells in vitro, we examined metformin's effect on proliferation in three HCC cell lines, namely, Alex, HLE and Huh7. Cells were grown in $10 \%$ fetal bovine serum (FBS) and treated with 1 or $5 \mathrm{mM}$ metformin, or without metformin as a control. To discern the direct relationship between the decrease in cell viability and the inhibition of cell proliferation, we followed the course of proliferation over 3 days after the addition of metformin. Metformin (0,1 and $5 \mathrm{mM}$ ) led to a decrease in cell proliferation in a dose- and timedependent manner in all three cell lines (Fig. 1), with the reduction being especially prominent in Huh7. On the other hand, metformin did not suppress the proliferation of normal hepatocytes. Thus the results showed that metformin inhibited the proliferation of HCC cells, but not the proliferation of normal hepatocytes (Hc cells).

Effects of metformin on cell cycle regulatory proteins in $H u h 7$. To study whether or not metformin affects the cell cycle in Huh7 cells, we examined the expression of various cell cycle-related molecules in Huh7 cells with and without metformin treatment using western blot analysis. The samples 

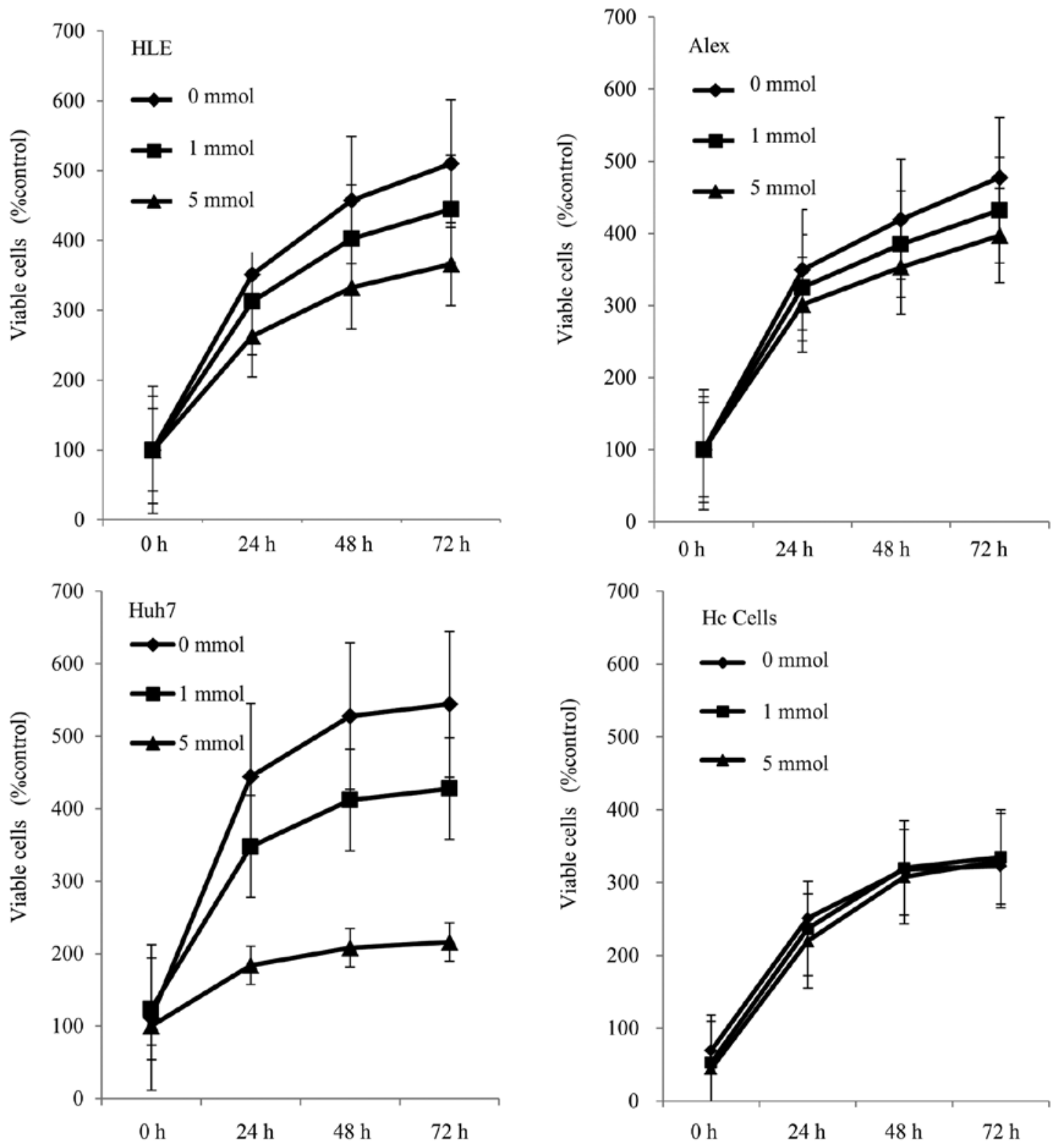

Figure 1. Metformin inhibits the proliferation of cultured hepatocellular carcinoma cells. HLE, Huh7, Alex and normal hepatocyte (Hc-Cells) cells were seeded at $1 \times 10^{4}$ cells per well in a 96-well plate. At $24 \mathrm{~h}$ after cell culture, metformin $(1 \mathrm{or} 5 \mathrm{mmol} / \mathrm{l})$ was added to the culture medium. A viability assay was performed daily from time 0 to $72 \mathrm{~h}$ after metformin treatment. For each HCC cell line, the number of viable cells in the wells treated with metformin $(1$ or $5 \mathrm{mmol} / \mathrm{l})$ was significantly decreased compared with the number of viable control cells at both 48 and $72 \mathrm{~h}$. On the other hand, metformin did not inhibit the proliferation of Hc-Cells. The data points represent the mean cell number from three independent cultures, and the error bars represent the SDs. For each HCC cell line, the conditions at 48 and $72 \mathrm{~h}$ were significantly $(\mathrm{p}<0.05)$ different compared with the control $(0 \mathrm{mmol})$.

were cells treated with $10 \mathrm{mM}$ metformin or left untreated for 24-72 $\mathrm{h}$. The most remarkable changes were the loss of cyclin D1, Cdk4 and cyclin E, a key protein implicated in the transition of the G0/G1 phase. In short, the cyclin D1, Cdk4 and cyclin E levels had already declined rapidly at $24 \mathrm{~h}$ after the addition of metformin, and were no longer detectable at 24 h (Fig. 2A).

As shown in Fig. 2A, we also studied the expression of two other cell cycle-related proteins, Cdk6 and Cdk2, implicated in the G0/G1 transition. The results showed that the catalytic subunit of cyclin E, Cdk2 and the catalytic subunit of cyclin D1, Cdk6 were almost unchanged at all time points after the addition of metformin (Fig. 2A). Similar things occurred in other cancer cell lines, such as Alex and HLE (data not shown). As an internal control, the amount of $\beta$-actin was also measured and was almost the same in each sample (Fig. 2A).

Next, to further investigate the inhibition of Huh7 cell proliferation in the presence of metformin, the cell cycle progression was examined using flow cytometry. We treated proliferating Huh7 cells with $10 \mathrm{mM}$ metformin for different durations. After the addition of $10 \mathrm{mM}$ metformin, an increasing number of cells started to accumulate in $\mathrm{G0}$ / $\mathrm{G} 1,60.7 \%$ after $24 \mathrm{~h}, 59.7 \%$ after $48 \mathrm{~h}$ and $67.7 \%$ by $72 \mathrm{~h}$ (Fig. 2B). In parallel, after the addition of $10 \mathrm{mM}$ metformin, we observed reductions in the percentage of cells in the 

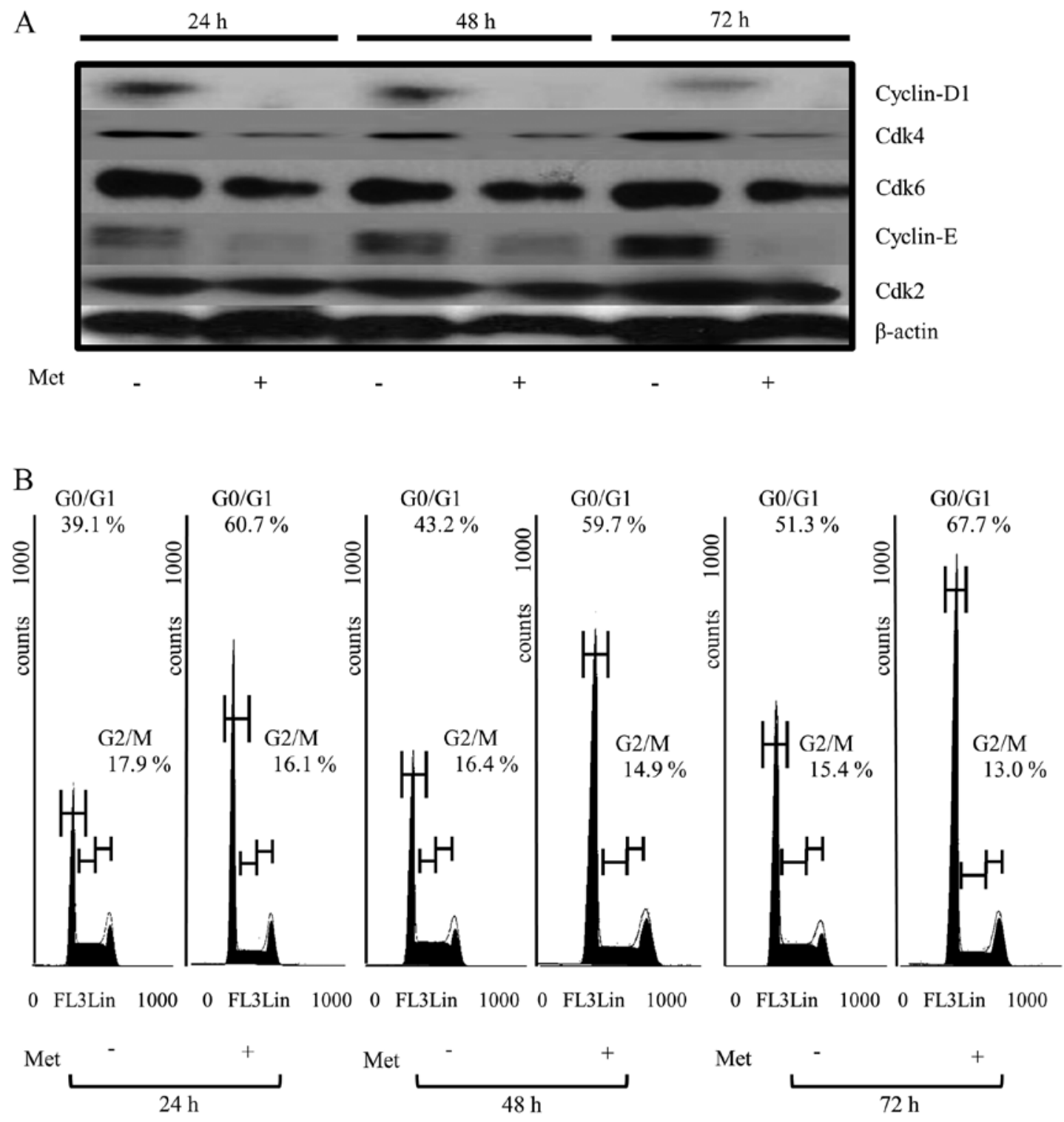

Figure 2. Metformin blocks the cell cycle in G0-G1 and affects the expression levels of the various cell cycle-regulatory proteins in Huh7 cells. (A) Western blot analysis of cyclin D1, Cdk4, Cdk6, cyclin E and Cdk2 at the indicated time points (24, 48 and $72 \mathrm{~h}$ ) after the addition of $5 \mathrm{mM}$ metformin in Huh7 cells. Note that the expressions of cyclin D1, Cdk4 and cyclin E were dramatically reduced in the Huh7 cells treated with metformin. (B) Flow cytometric analysis of proliferating Huh7 cells at 24, 48 and $72 \mathrm{~h}$ after the addition of $5 \mathrm{mmol}$ metformin. Note that metformin inhibited the cell cycle progression from G0-G1 into S phase at 24 to $72 \mathrm{~h}$ in Huh7 cells. The results are representative of three independent experiments.

S phase and G2/M phase. These data suggest that metformin inhibits the cell cycle progression from G0/G1 into $\mathrm{S}$ phase, resulting in G1 cell cycle arrest.

Metformin inhibits tumor proliferation in vivo. In order to determine whether metformin could affect tumor growth in vivo, metformin was injected daily intraperitoneally (i.p.) at 1 or $2 \mathrm{mg}$ per day in xenografted mice. Animals in the control group received i.p. administration of the vehicle (PBS). As shown in Fig. 3A and B, animals in the control group developed rapidly-growing subcutaneous HCC. On the basis of the integrated values of the tumor growth curves, i.p. administration of metformin led to a substantial inhibition of tumor growth, by $25 \%(1 \mathrm{mg} /$ day) and $52 \%(2 \mathrm{mg} /$ day) (Fig. 3A and $\mathrm{B})$. These growth rates were significantly above those of the control (both $\mathrm{p}<0.01$, respectively). In addition, $2 \mathrm{mg}$ metformin treatment significantly inhibited tumor growth compared with that in $1 \mathrm{mg}$ metformin-treated mice $(\mathrm{p}<0.05)$. All animals remained alive throughout the experiment, and metformin exhibited no apparent changes in mice and did not affect their weight (data not shown).

To determine whether metformin also affected cell cycle-regulatory protein levels in vivo, we performed a western blot analysis in tumorous tissues obtained from the xenograft experiments. Metformin (1-2 mg dose) reduced the levels of cell cycle-related molecules (cyclin D1, Cdk4, cyclin E) in treated tumors compared with controls (Fig. 3C). However, the expressions of Cdk2 and Cdk6 in tumorous tissue remained unchanged. These data were similar to the results of the in vitro observation (Fig. 2A). In summary, 


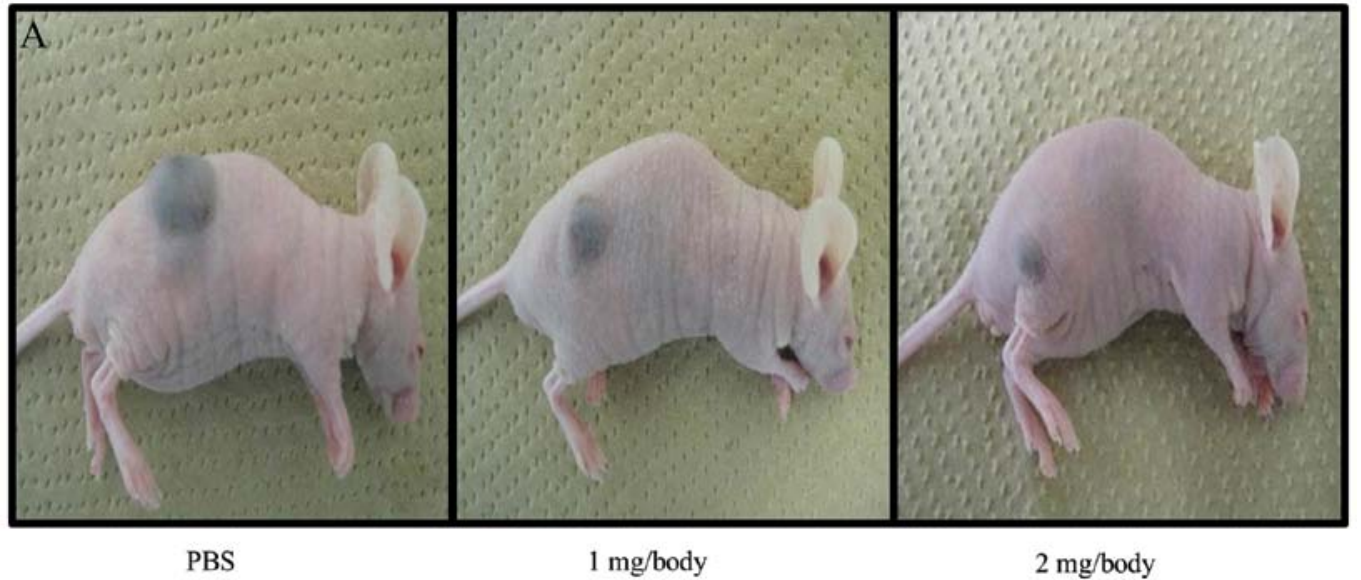

B
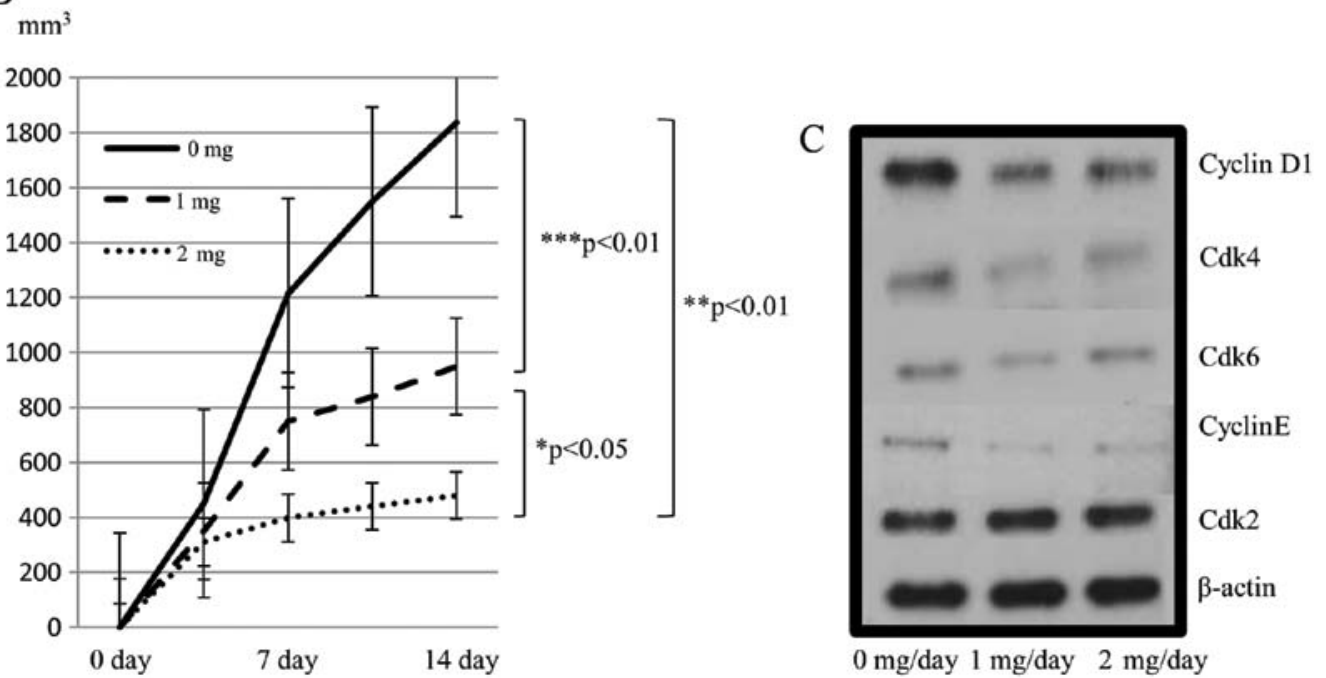

Figure 3. In vivo antitumor effects of metformin on established HCC in nude mice. (A) Representative photographs of the gross Huh7 tumors from nude mice left untreated as i) a control, or ii) treated with $1 \mathrm{mg}$ metformin or iii) $2 \mathrm{mg}$ metformin. (B) Huh7 cells implanted subcutaneously into the flank region of nude mice. When a tumor became palpable in nude mice, 1 and $2 \mathrm{mg}$ metformin was injected intraperitoneally for 2 weeks, 5 times per week. Animals in the control group developed rapidly-growing subcutaneous HCC. In contrast, animals in the metformin-treated groups exhibited significantly retarded tumor development. The tumors in the mice treated with $2 \mathrm{mg}$ metformin were significantly smaller compared with those in the mice treated with $1 \mathrm{mg}$ metformin ("p<0.05) and the control $\left({ }^{* *} \mathrm{p}<0.01\right)$. The tumor size in the mice treated with $1 \mathrm{mg}$ metformin was also significantly smaller than that of control nude mice $\left({ }^{* * *} \mathrm{p}<0.01\right)$. Each data point represents the mean \pm SD of 10 animals. Tumor volumes $\left(\mathrm{mm}^{3}\right)$ are expressed as follows: tumor volume $\left(\mathrm{mm}^{3}\right)=\left[\right.$ tumor length $(\mathrm{mm}) \mathrm{x}$ tumor width $\left.(\mathrm{mm})^{2}\right] / 2$. (C) Representative western blot analysis of cell cycle-regulatory protein expression in tumors from mice treated with metformin and tumors from untreated control mice. Various cell cycle-related proteins (cyclin D1, Cdk4, cyclin E) in the tumorous tissues treated with metformin were reduced as compared with control nude mice. These results were similar to those of the study in vitro.

in the in vivo study, as in the in vitro study, metformin decreased tumor growth by reducing cell cycle-regulatory protein levels, especially in cyclin D1, Cdk4 and cyclin E, resulting in $\mathrm{G} 1$ cell cycle arrest.

Differences in phosphorylated-receptor tyrosine kinases $(p-R T K s)$ between metformin-treated and control samples in vitro and in vivo. We used a phosphorylated-RTK array system to identify the key RTKs associated with the antitumor effect of metformin. By using an antibody array (Fig. 4A), we simultaneously screened the expressions of 42 different activated RTKs in Huh7 cells and tumorous tissues with or without metformin. In the in vitro study, the expressions of phosphorylated-epidermal growth factor (p-EGFR) and phosphorylated-insulin-like growth factor-1 receptor (p-IGF$1 \mathrm{R}$ ) in Huh7 cells were reduced by treatment with metformin
(Fig. 4B), while in the in vivo study, the levels of $\mathrm{p}$-EGFR and Mer in tumorous tissues (Fig. 4C) were reduced by the treatment with metformin. The densitometric ratios of the p-EGFR and $\mathrm{p}-\mathrm{IGF}-1 \mathrm{R}$ spots of the metformin-treated cell lines to the non-treated cell lines were 51 and $12 \%$, respectively (Fig. 4D). In addition, the ratios of p-EGFR and Mer of the metformin-treated tumorous tissue to the non-treated tissue were 67 and 55\%, respectively (Fig. 4E).

Differences in angiogenesis in vitro and in vivo with and without metformin. We used an angiogenesis array system to identify the key angiogenesis-related molecules associated with the antitumor effect of metformin. The antibody array (Fig. 5A) allowed us to simultaneously screen the expressions of 20 different angiogenesis molecules in Huh7 cells (Fig. 5B) and tumor tissues (Fig. 5C) with or without metformin. 


\begin{tabular}{|c|c|c|c|c|c|c|c|c|c|c|c|}
\hline $\begin{array}{c}\text { PY- } \\
\text { Control }\end{array}$ & & & & & & & & & & & $\begin{array}{c}\text { PY- } \\
\text { Control }\end{array}$ \\
\hline & ErbB2 & ErbB3 & ErbB4 & FGF R1 & FGF R $2 \alpha$ & FGF R3 & FGF R4 & $\begin{array}{c}\text { Insulin } \\
\mathrm{R}\end{array}$ & & Axi & Dtk \\
\hline & HGF R & MSP R & $\begin{array}{l}\text { PDGF } \\
R \alpha\end{array}$ & $\begin{array}{c}\text { PDGF } \\
\mathrm{R} \beta\end{array}$ & SCF R & Fit-3 & $\begin{array}{c}\text { M-CSF } \\
\text { R }\end{array}$ & c-Ret & ROR1 & ROR2 & Tie-1 \\
\hline Tie-2 & TrkA & TrkB & TrkC & $\begin{array}{c}\text { VEGF } \\
\text { R1 }\end{array}$ & $\begin{array}{c}\text { VeGF } \\
\text { R2 }\end{array}$ & $\begin{array}{c}\text { VEGF } \\
\text { R3 }\end{array}$ & MuSK & EphA1 & EphA2 & EphA3 & EphA4 \\
\hline EphA6 & EphA7 & EphB1 & EphB2 & EphB4 & EphB6 & $\begin{array}{l}\text { Mouse } \\
\text { IgG1 }\end{array}$ & $\begin{array}{l}\text { Mouse } \\
\text { IgG2A }\end{array}$ & $\begin{array}{l}\text { Mouse } \\
\text { IgG2B }\end{array}$ & Goat IgG & PBS & \\
\hline $\begin{array}{c}\text { PY- } \\
\text { Control }\end{array}$ & & & & & & & & & & & $\begin{array}{c}\text { PY- } \\
\text { Control }\end{array}$ \\
\hline
\end{tabular}

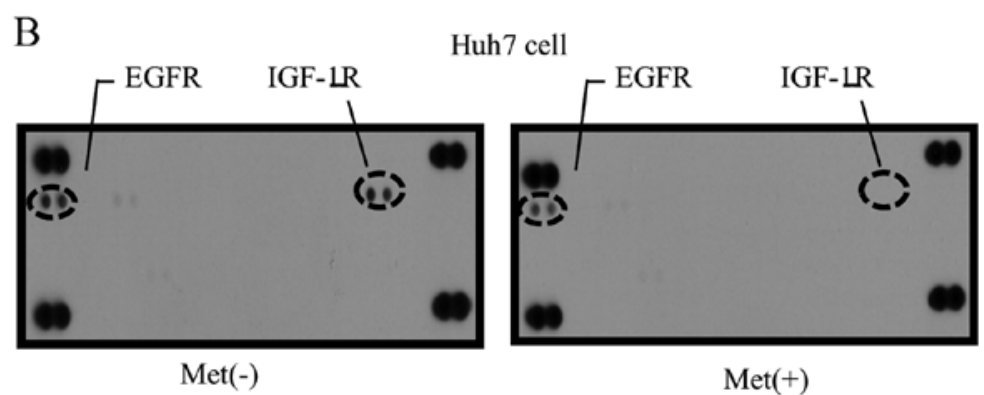

$\mathrm{C}$

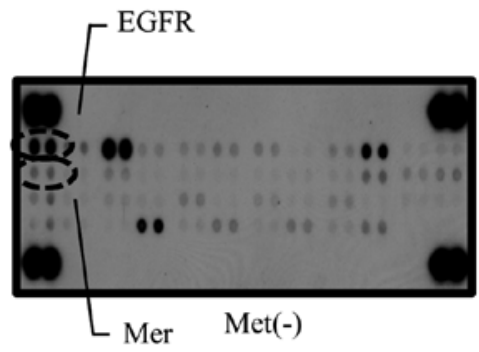

Huh7 tissue

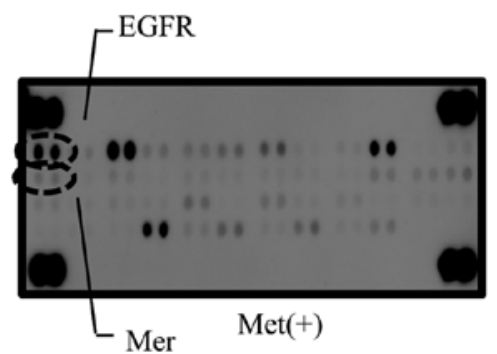

$\mathrm{D}$

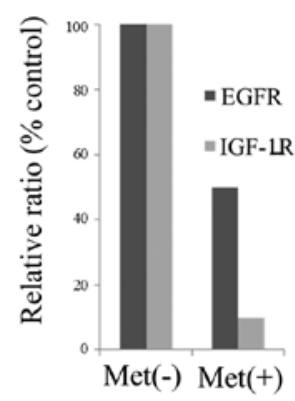

$\mathrm{E}$

Huh7 tissue

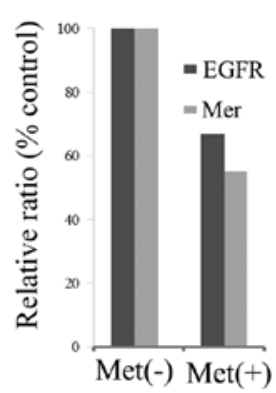

Figure 4. (A) Template showing the location of tyrosine kinase antibody spotted onto the RayBio Human Phospho Array Kit. PY-Control, phospho-tyrosine positive control; EGFR, epidermal growth factor receptor; ErbB2, v-erb-b2 erythroblastic leukemia viral oncogene homolog 2; ErbB3, v-erb-b2 erythroblastic leukemia viral oncogene homolog 3; ErbB4, v-erb-a erythroblastic leukemia viral oncogene homolog 4; FGFR, fibroblast growth factor receptor; Insulin R, insulin receptor; IGF-1R, insulin-like growth factor I receptor; Axl, Axl receptor tyrosine kinase; Dtk, developmental receptor tyrosine kinase; Mer, tyrosine-protein kinase Mer; HGFR, hepatocyte growth factor receptor; MSPR, macrophage stimulatory protein receptor; PDGFR, platelet-derived growth factor receptor; SCFR, stem-cell factor receptor; Flt-3, Fms-like tyrosine kinase 3; M-CSFR, macrophage colony-stimulating factor receptor; c-Ret, receptor tyrosine kinase c-ret; ROR, receptor tyrosine kinase-like orphan receptor; Tie, tyrosine kinase with immunoglobulin-like and EGF-like domains; TrkA, neurotrophic tyrosine kinase, receptor, type 1; TrkB, neurotrophic tyrosine kinase, receptor, type 2; TrkC, neurotrophic tyrosine kinase, receptor, type 3; VEGFR, vascular endothelial growth factor receptor; MuSK, muscle, skeletal, receptor tyrosine kinase; Eph, Eph receptor; PBS, phosphate-buffered saline. (B and C) Representative expression of various p-RTKs in $\mathrm{HCC}$ cell lines and tumors with or without metformin treatment. The reduced expression levels of p-EGFR and p-IGF-1R were detected in metformin-treated cell lines and the reduced p-EGFR and p-Mer were detacted in the tumorous tissues obtained from xenograft animal treated with metformin. (D) The densitometric ratios of the p-EGFR and p-IGF-1R spots of the metformin-treated cell line to the non-treated one were 50.1 and $7.8 \%$, respectively. (E) The ratios of the p-EGFR and p-Mer spots of metformin-treated tumorous tissue to the non-treated tumorous tissue were 55.2 and $67.1 \%$, respectively.

Among the 20 angiogenesis molecules screened, angiogenin was reduced in in vitro and in vivo study with metformin treatment. The densitometric densities on angiogenin in cell line and tumorous tissue were visualized in black and white, respectively. The densitometric ratios of the angiogenin spots from metformin-treated cell line and tumorous tissues to those of cell line and tumorous tissues not treated with metformin were 51\% (Fig. 5D) and 54\% (Fig. 5E).
Differences in miRNA expression between the metformin-treated and control cell lines. Using a custom microarray platform, we analyzed the expression levels of 985 human miRNA probes in the cell lines treated with metformin and the control cell line. As shown in Table I, when the expression of miRNAs was studied in Huh7 cells treated with $10 \mathrm{mM}$ metformin and without metformin in vitro, 33 of 985 miRNAs were significantly upregulated in Huh7 cells 


\begin{tabular}{|c|c|c|c|c|c|c|c|c|}
\hline A & A & B & C & D & F & G & H \\
\hline 1 & POS & POS & NEG & NEG & Angiogenin & EGF & ENA-78 & bFGF \\
\hline 2 & POS & POS & NEG & NEG & Angiogenin & EGF & ENA-78 & bFGF \\
\hline 3 & GRO & IFN- $\gamma$ & IGF-I & IL-6 & IL-8 & LEPTIN & MCP-1 & PDGF-BB \\
\hline 4 & GRO & IFN- $\gamma$ & IGF-I & IL-6 & IL-8 & LEPTIN & MCP-1 & PDGF-BB \\
\hline 5 & PIGF & RANTES & TGF- $\beta 1$ & TIMP-1 & TIMP-2 & TPO & VEGF & VEGF-D \\
\hline 6 & PIGF & RANTES & TGF- $\beta 1$ & TIMP-1 & TIMP-2 & TPO & VEGF & VEGF-D \\
\hline 7 & BLANK & BLANK & BLANK & BLANK & BLANK & BLANK & NEG & POS \\
\hline 8 & BLANK & BLANK & BLANK & BLANK & BLANK & BLANK & NEG & POS \\
\hline
\end{tabular}

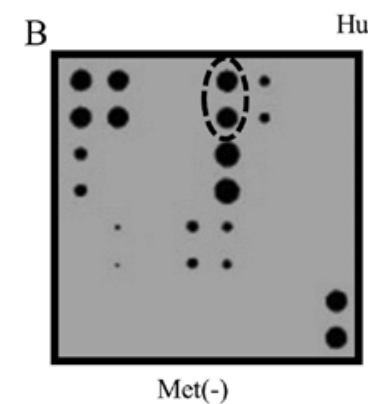

Huh7 cell

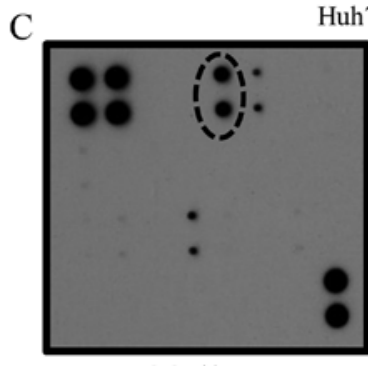

$\operatorname{Met}(-)$

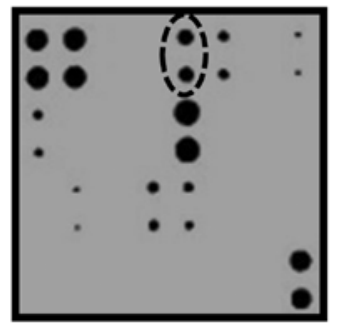

$\operatorname{Met}(+)$

Huh7 tissue
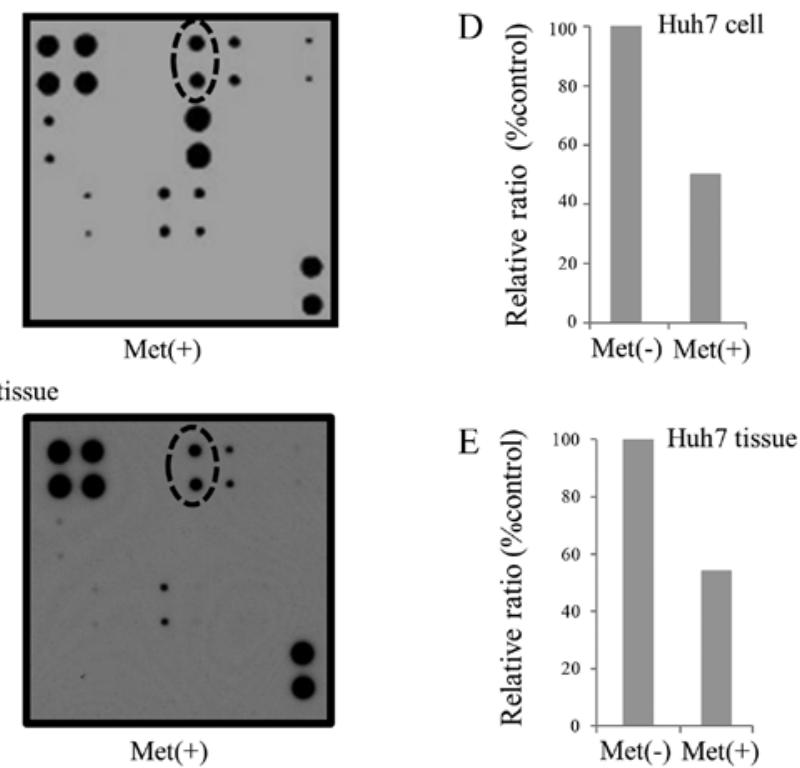

Figure 5. (A) Template showing the location of angiogenesis antibody spotted onto the RayBio human angiogenesis antibody array kit. Pos, positive control; NEG, negative control; Angiogenin, angiogenin; EGF, endothelial growth factor; ENA-78, epithelial neutrophil-activating protein 78; bFGF, basic fibroblast growth factor; GRO, growth related oncogene; IFN- $\gamma$, interferon $\gamma$; IGF-1, insulin-like growth factor-I; IL-6, interleukin-6; IL-8, interleukin-8; LEPTIN, leptin; MCP-1, monocyte chemotactic protein-1; PDGF-BB, platelet-derived growth factor BB; PIGF, PIGF, placental growth factor; RANTES, regulated upon activation normal $\mathrm{T}$ cell expressed and presumably secreted; TGF- $\beta 1$, transforming growth factor- $\beta 1$; TIMP-1, tissue inhibitor of metalloproteinase-1; TIMP-2, tissue inhibitor of metalloproteinase-2; Thrombopoietin; VEGF, vascular endothelial growth factor; VEGF-D, vascular endothelial growth factor-D; BLANK, blank. (B and C) Representative expression of various angiogenic molecules in Huh7 cell lines and tumors with or without metformin treatment, respectively. A reduction in angiogenin was detected in metformin-treated cell lines and tumors. (D) The densitometric ratio of the angiogenin spots of the metformin-treated cell line to the non-treated one was $52.1 \%$. (E) The ratio of the angiogenin of tumorous tissue of nude mice with metformin-treatment to non-treated tissue was $54.0 \%$.

at $72 \mathrm{~h}$ after metformin treatment (Table I), while 18 of 985 miRNAs downregulated (Table II).

Unsupervised hierarchical clustering analysis, using Pearson's correlation, showed that cell lines treated with metformin clustered together and separately from the untreated cell lines (Fig. 6). These subsets of 119 microRNAs in cell lines exhibited $>1.5$-fold alterations in expression levels between the metformin-treated and control groups.

\section{Discussion}

HCC is the sixth most common malignancy and the third most common cause of cancer-related death worldwide (1). Conventional chemotherapy does not provide significant clin- ical benefits or prolonged survival for patients with advanced HCC (23). Therefore, it is necessary to identify new therapies for the treatment of HCC.

The role of the anti-diabetic drug metformin in glucose and fatty acid metabolism is very well known $(20,22)$. Recent data suggest that metformin was shown to protect from cancer and inhibit the proliferation of various human cancer cell types, such as those of the prostate $(6)$, breast $(7)$, colon $(8,9)$, stomach (10), and esophagus (11) and HCC (12). However, the antitumor mechanism of metformin in various cancers, including hepatocellular carcinoma (HCC), has not been fully clarified. Here we show that metformin inhibits the growth of HCC cells and tumorigenesis in vitro and in vivo. In addition, we have identified miRNAs, receptor-type tyrosine kinase 
Table I. Statistical results and chromosomal of miRNAs upregulated in Huh7 cells treated with metformin.

\begin{tabular}{|c|c|c|c|}
\hline miRNAs & $\begin{array}{c}\text { Fold } \\
\text { (treated/non-treated) } \\
\text { mean } \pm \text { SD }\end{array}$ & P-value & $\begin{array}{l}\text { Chromosomal } \\
\text { localization }\end{array}$ \\
\hline hsa-miR-1304 & $2.29 \pm 0.75$ & 0.0307 & $15 \mathrm{q} 21.2$ \\
\hline hsa-miR-1270 & $2.24 \pm 0.91$ & 0.0095 & 19 \\
\hline hsa-miR-324-5p & $1.98 \pm 0.69$ & 0.0228 & $17 \mathrm{p} 13.1$ \\
\hline hsa-miR-125a-5p & $1.95 \pm 0.12$ & 0.0096 & $19 \mathrm{q} 13.41$ \\
\hline hsa-miR-23a & $1.87 \pm 0.08$ & 0.0055 & $19 \mathrm{p} 13.13$ \\
\hline hsa-let-7a & $1.82 \pm 0.34$ & 0.0099 & $9 \mathrm{q} 22.32$ \\
\hline hsa-miR-3143 & $1.81 \pm 0.36$ & 0.0411 & 6 \\
\hline hsa-miR-3607-5p & $1.78 \pm 0.26$ & 0.0034 & 5 \\
\hline hsa-miR-1178 & $1.76 \pm 0.20$ & 0.0204 & $12 \mathrm{q} 24.23$ \\
\hline hsa-miR-181a & $1.75 \pm 0.24$ & 0.0047 & 1q32.1 \\
\hline hsa-miR-99b & $1.74 \pm 0.13$ & 0.0099 & $19 \mathrm{q} 13.41$ \\
\hline hsa-miR-142-3p & $1.74 \pm 0.42$ & 0.0147 & $17 \mathrm{q} 22$ \\
\hline hsa-let-7e & $1.74 \pm 0.18$ & 0.0066 & $19 q 13.41$ \\
\hline hsa-miR-27a & $1.72 \pm 0.19$ & 0.0061 & $19 \mathrm{p} 13.13$ \\
\hline hsa-miR-502-5p & $1.69 \pm 0.37$ & 0.0248 & Xp11.23 \\
\hline hsa-miR-23b & $1.68 \pm 0.40$ & 0.0229 & $9 \mathrm{q} 22.32$ \\
\hline hsa-miR-563 & $1.67 \pm 0.44$ & 0.0156 & $3 \mathrm{p} 25.1$ \\
\hline hsa-miR-181d & $1.65 \pm 0.11$ & 0.0363 & $19 q 13.13$ \\
\hline hsa-miR-29a & $1.64 \pm 0.36$ & 0.0443 & $7 \mathrm{q} 32.3$ \\
\hline hsa-miR-612 & $1.64 \pm 0.17$ & 0.0346 & $11 \mathrm{q} 13.1$ \\
\hline hsa-miR-551b & $1.64 \pm 0.40$ & 0.0368 & $3 q 26.2$ \\
\hline hsa-miR-3616-3p & $1.63 \pm 0.20$ & 0.0095 & 20 \\
\hline hsa-miR-34a & $1.58 \pm 0.17$ & 0.0162 & $1 \mathrm{p} 36.22$ \\
\hline hsa-miR-185 & $1.56 \pm 0.21$ & 0.0152 & $22 \mathrm{q} 11.21$ \\
\hline hsa-miR-613 & $1.54 \pm 0.16$ & 0.0193 & $12 \mathrm{p} 13.1$ \\
\hline hsa-miR-378 & $1.54 \pm 0.06$ & 0.0007 & $5 q 32$ \\
\hline hsa-miR-21* & $1.53 \pm 0.36$ & 0.0259 & $17 \mathrm{q} 23.1$ \\
\hline hsa-miR-181b & $1.51 \pm 0.24$ & 0.0221 & $1 \mathrm{q} 32.1$ \\
\hline hsa-miR-26a & $1.51 \pm 0.25$ & 0.0083 & $3 q 22.2$ \\
\hline hsa-miR-3649 & $1.51 \pm 0.22$ & 0.0488 & 12 \\
\hline hsa-miR-455-3p & $1.51 \pm 0.04$ & 0.0045 & $9 \mathrm{q} 32$ \\
\hline hsa-miR-449a & $1.5 \pm 0.33$ & 0.0263 & $5 q 11.2$ \\
\hline hsa-miR-24 & $1.5 \pm 0.03$ & 0.0094 & $9 \mathrm{q} 22.32$ \\
\hline
\end{tabular}

and angiogenesis molecules associated with the antitumor effect of metformin in HCC.

In the present study, metformin led to a strong, dose-dependent inhibition of cell proliferation in all HCC cell lines. However, to our surprise, metformin did not inhibit the proliferation of normal hepatocytes. These data suggest that metformin exhibits an anti-proliferation effect on HCC cells, but does not have an anti-proliferation effect on normal hepatocytes. These results suggest that metformin would be very effective for HCC treatment, since it specifically suppressed the proliferation in cancer cells, but not in normal cells.
Table II. Statistical results and chromosomal of miRNAs downregulated in Huh7 cells treated with metformin.

\begin{tabular}{|c|c|c|c|}
\hline miRNAs & $\begin{array}{c}\text { Fold } \\
\text { (treated/non-treated) } \\
\text { mean } \pm \text { SD }\end{array}$ & P-value & $\begin{array}{c}\text { Chromosomal } \\
\text { localization }\end{array}$ \\
\hline hsa-miR-518f & $0.35 \pm 0.07$ & 0.0485 & $19 q 13.42$ \\
\hline hsa-miR-1180 & $0.42 \pm 0.20$ & 0.0460 & 17 \\
\hline hsa-miR-3686 & $0.43 \pm 0.14$ & 0.0372 & 8 \\
\hline hsa-miR-217 & $0.48 \pm 0.23$ & 0.0494 & 2p16.1 \\
\hline hsa-miR-553 & $0.49 \pm 0.12$ & 0.0031 & $1 \mathrm{p} 21.2$ \\
\hline hsa-miR-4296 & $0.53 \pm 0.12$ & 0.0225 & 10 \\
\hline hsa-miR-3689a-5p & $0.54 \pm 0.21$ & 0.0391 & 9 \\
\hline hsa-miR-4295 & $0.55 \pm 0.09$ & 0.0200 & 10 \\
\hline hsa-miR-1203 & $0.58 \pm 0.05$ & 0.0111 & 17 \\
\hline hsa-miR-302b & $0.59 \pm 0.07$ & 0.0327 & $4 q 25$ \\
\hline hsa-miR-943 & $0.60 \pm 0.16$ & 0.0443 & $4 p 16.3$ \\
\hline hsa-miR-551b* & $0.61 \pm 0.14$ & 0.0066 & $3 q 26.2$ \\
\hline hsa-miR-3663-5p & $0.65 \pm 0.12$ & 0.0220 & 10 \\
\hline hsa-miR-1307 & $0.72 \pm 0.05$ & 0.0110 & 10 \\
\hline hsa-miR-130b & $0.74 \pm 0.02$ & 0.0283 & 22 \\
\hline hsa-miR-1227 & $0.76 \pm 0.11$ & 0.0411 & 19 \\
\hline hsa-miR-658 & $0.79 \pm 0.07$ & 0.0157 & $22 \mathrm{q} 13.1$ \\
\hline hsa-miR-126* & $0.87 \pm 0.07$ & 0.0312 & $9 \mathrm{q} 34.3$ \\
\hline
\end{tabular}

In previous reports, downregulation of cyclin D1 in response to metformin has been demonstrated in various cancer cell lines $(8,9)$. We have also reported that cyclin D1 was reduced in gastric cancer cells treated with metformin in vitro. In the present study, we have also shown that the major cell cycle regulators (cyclin D1, Cdk4 and cyclin E) could be intracellular targets of the metformin-mediated anti-proliferative effect in HCC. To be sure, flow cytometry also revealed that metformin arrested $\mathrm{HCC}$ cells at the $\mathrm{G} 0 / \mathrm{G} 1$ phase in vitro.

An in vivo experiment using subcutaneous HCC-bearing athymic nude mice also demonstrated that metformin markedly suppressed the growth of HCC, and the expression levels of numerous cell cycle-related molecules (cyclin D1, Cdk4, cyclin E) were found to be reduced by treatment with metformin, indicating that metformin may inhibit the expression of cell cycle-related molecules. These data suggest that the antitumor effect of metformin may be related to the role of G1 arrest of HCC cells.

Our in vitro study was performed using a higher dose of metformin than the human therapeutic concentration ( 6 to $30 \mu \mathrm{M})$. This has been a previously raised criticism of similar work in other cancer cell types, such as the prostate (6), breast (7), colon $(8,9)$, stomach (10), and esophagus (11) and HCC (12). However, it is important to consider that cells in culture are grown under hyperglycemic conditions (24). Tissue culture media alone contains high concentrations of glucose, and $5-10 \%$ fetal bovine serum is typically added, resulting in excessive growth stimulation. This may explain why the doses of metformin required to realize the antitumor 


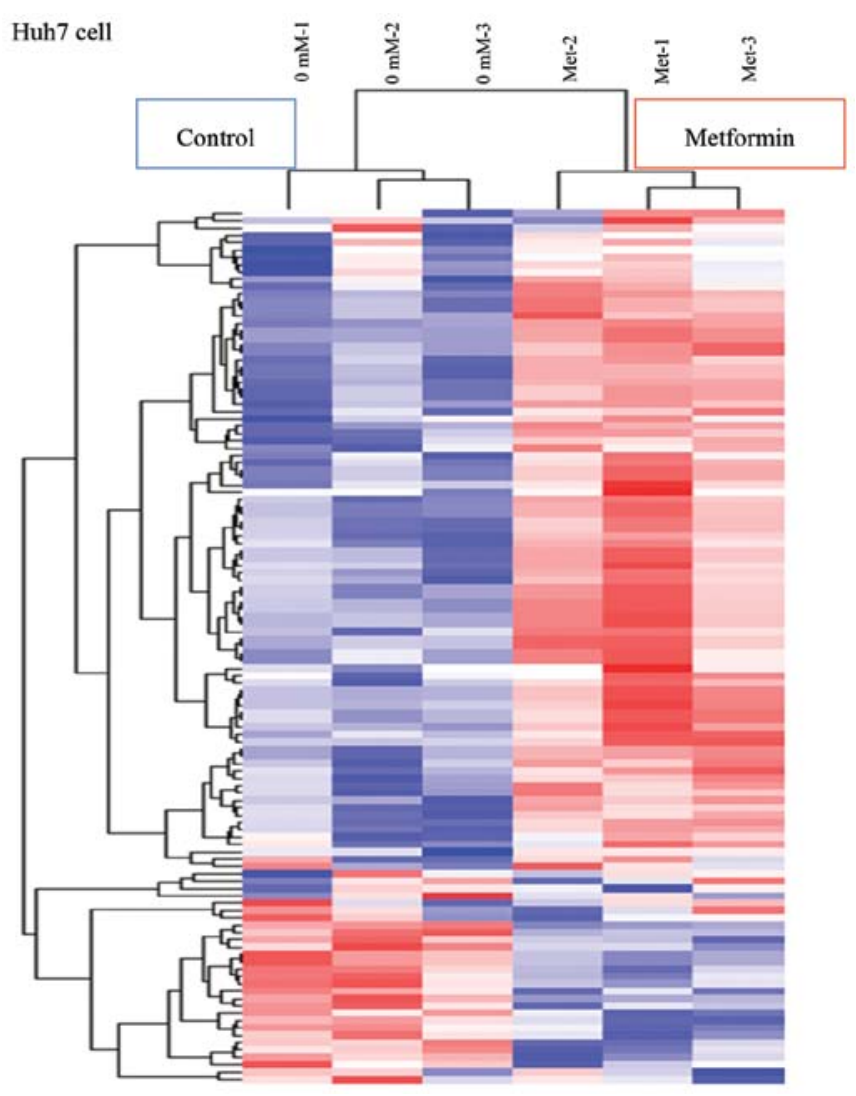

Figure 6. Hierarchical clustering of the Huh7 cells treated with metformin and those left untreated. Huh7 cells were clustered according to the expression profiles of 119 differently expressed miRNAs between Huh7 cells treated with metformin and those treated without it. The analyzed samples are in columns and the miRNAs are presented in rows. The miRNA clustering tree is shown on the left and the sample-clustering tree appears at the top. The color scale shown at the top illustrates the relative expression level of miRNAs; red represents a high expression level and blue represents a low expression level.

effects in a cell culture system are higher than those used in diabetic patients.

Metformin leads to changes in various protein phosphorylation. In the present study, we have shown that metformin reduced the activation of the EGFR, IGF-1R and Mer in vitro and/or in vivo. In regard to $\mathrm{p}$-EGFR and $\mathrm{p}-\mathrm{IGF}-1 \mathrm{R}$, some studies $(1,2)$, including a report by our group (23), have also reported that metformin reduced the expression of $\mathrm{p}$-EGFR and p-IGF-1R in breast (24), pancreas (26) and gastric cancer $(10,25)$. However, to date, there have been no reports in which metformin inhibited Mer activation. The upregulation of Mer is detected in various cancers $(27,28)$. Mer prevents apoptosis without stimulating proliferation (28), whereas it increases without inhibiting apoptosis (29). The mechanism of metformin's anti-proliferation effect in cancer cells may occur through inactivation of Mer. In addition, our studies suggest that metformin may reduce the expression levels of $\mathrm{p}$-EGFR, p-IGFR and p-Mer in many cancers, including HCC and their molecules may become the new target factor of the treatment in HCC. In addition, the pathway of EGFR and IGF-1R plays a role in controlling cell cycle events. EGFR and IGF-R1 are upregulated by many proteins involved in cell cycle progression, such as cyclin D1 and Cdk4. Therefore, metformin blocked the cell cycle in G0/G1 in vitro and in vivo through the reduction of the activity of EGFR and IGF-1R.

In the present study, metformin was found to reduce only angiogenin out of 20 angiogenesis-related proteins in an analysis using a protein array. Angiogenin is not only related to angiogenesis, but also possesses the ability to promote cell growth (30). In addition, some previous reports (31) have shown that enhanced expression of angiogenin is associated with the progression of HCC. These data suggest that the antitumor effect of metformin may be due to a reduction of angiogenin.

To identify miRNAs associated with the antitumor effect of metformin, we used a miRNA expression array and measured the variations in miRNA profiles in HCC cell lines in culture treated with metformin compared to those not treated with metformin. The cluster analyses we performed clearly demonstrated that metformin treatment affects the extent of miRNA expression in cultured cells. In the analyses, we selected sets of miRNAs for which the expression levels were altered significantly before and after metformin treatment. We identified 51 miRNAs differentially expressed (33 upregulated and 18 downregulated) in culture. These miRNAs are meaningful candidates to gauge the effectiveness of metformin treatment and to provide clues to the molecular basis of metformin's anticancer effects, particularly when mediated with miRNAs.

We found that members of the let-7 family (let-7a, let-7b and let-7e) are upregulated in cultured cells treated with metformin. The human let-7 family contains 13 members and is widely recognized as a class of miRNAs producing a tumor-suppressing effect (32). Consistent with this event, downregulation of let-7 family members has been reported in many cancers, such as lung (33), breast (34), colorectal cancer (35), melanoma (36), gastric cancer (10) and HCC (37). The let-7 family acts as a tumor suppressor by binding its target oncogenes, including Ras (38), HMGA2 (39) and c-Myc (40). Therefore, the downregulated let-7 plays an important role in the development of various cancers, including HCC. Collectively, these findings suggest that the suppression of cancer cell proliferation by metformin may be at least partly due to the upregulation of let-7a, let-7b and let-7e.

In the present study, metformin treatment resulted in altered expression of a surprising number of diverse miRNAs. The miRNAs upregulated in HCC cells treated with metformin included miRNAs that are overexpressed in HCC, such as miR-23a, miR-27A, miR-34a, miR-21, miR-24 and miR-324-5p, and miRNAs that are reduced in HCC, such as miR-7a, miR-7b and miR-7e, miR-23b, miR-29a, miR-26a, miR-81a, miR-142-3p and miR-378 $(41,42)$. We speculate that the former group of miRNAs may be involved in survival responses that are altered in malignant cells, whereas the latter group may reflect the general cellular responses to deathinducing stimuli. However, additional detailed studies will be needed to assess whether or not each miRNA reflects a cause or a consequence of exposure to metformin treatment.

In conclusion, our results revealed that metformin inhibits human HCC cell proliferation and tumor growth, possibly by suppressing the cell cycle-related molecules via alteration of miRNAs. Metformin is a drug widely used for the treatment of type 2 diabetes with limited side-effects. Therefore, metformin may become a novel and effective therapy for the treatment and long-term management of HCC, providing additional benefits at low cost. 


\section{References}

1. Parkin DM, Bray F, Ferlay J and Pisani P: Global cancer statistics, 2002. CA Cancer J Clin 55: 74-108, 2005.

2. Venook AP, Papandreou C, Furuse J and de Guevara LL: The incidence and epidemiology of hepatocellular carcinoma: A global and regional perspective. Oncologist 15: 5-13, 2010.

3. Witters LA: The blooming of the French lilac. J Clin Invest 108 1105-1107, 2001.

4. Barriere G, Tartary $M$ and Rigaud M: Metformin: A rising star to fight the epithelial mesenchymal transition in oncology. Anticancer Agents Med Chem 13: 333-340, 2013.

5. Lee MS, Hsu CC, Wahlqvist ML, Tsai HN, Chang YH and Huang YC: Type 2 diabetes increases and metformin reduces total, colorectal, liver and pancreatic cancer incidences in taiwanese: A representative population prospective cohort study of 800,000 individuals. BMC Cancer 11: 20, 2011.

6. Ben Sahra I, Laurent K, Loubat A, et al: The antidiabetic drug metformin exerts an antitumoral effect in vitro and in vivo through a decrease of cyclin D1 level. Oncogene 27: 3576-3586, 2008.

7. Brown KA, Hunger NI, Docanto M and Simpson ER: Metformin inhibits aromatase expression in human breast adipose stromal cells via stimulation of AMP-activated protein kinase. Breast Cancer Res Treat 123: 591-596, 2010.

8. Hosono K, Endo H, Takahashi H, et al: Metformin suppresses azoxymethane-induced colorectal aberrant crypt foci by activating AMP-activated protein kinase. Mol Carcinog 49: 662-671, 2010

9. Zhou XZ, Xue YM, Zhu B and Sha JP: Effects of metformin on proliferation of human colon carcinoma cell line SW-480. Nan Fang Yi Ke Da Xue Xue Bao 30: 1935-1938, 2010 (In Chinese).

10. Kato K, Gong J, Iwama $\mathrm{H}$, et al: The antidiabetic drug metformin inhibits gastric cancer cell proliferation in vitro and in vivo. Mol Cancer Ther 11: 549-560, 2012.

11. Kobayashi M, Kato K, Iwama H, et al: Antitumor effect of metformin in esophageal cancer: In vitro study. Int J Oncol 42: $517-524,2012$

12. Qu Z, Zhang Y, Liao M, Chen Y, Zhao J and Pan Y: In vitro and in vivo antitumoral action of metformin on hepatocellular carcinoma. Hepatol Res 42: 922-933, 2012.

13. Landgraf $\mathrm{P}$, Rusu M, Sheridan R, et al: A mammalian microRNA expression atlas based on small RNA library sequencing. Cell 129: 1401-1414, 2007.

14. Ji J, Yamashita T, Budhu A, et al: Identification of microRNA-181 by genome-wide screening as a critical player in EpCAM-positive hepatic cancer stem cells. Hepatology 50: 472-480, 2009.

15. Callegari E, Elamin BK, Giannone F, et al: Liver tumorigenicity promoted by microRNA-221 in a mouse transgenic model. Hepatology 56: 1025-1033, 2012.

16. Masaki T, Shiratori Y, Rengifo W, et al: Hepatocellular carcinoma cell cycle: Study of long-evans cinnamon rats. Hepatology 32: 711-720, 2000.

17. Masaki T, Shiratori Y, Rengifo W, et al: Cyclins and cyclin-dependent kinases: Comparative study of hepatocellular carcinoma versus cirrhosis. Hepatology 37: 534-543, 2003.

18. Masaki T, Tokuda M, Yoshida S, et al: Comparison study of the expressions of myristoylated alanine-rich $\mathrm{C}$ kinase substrate in hepatocellular carcinoma, liver cirrhosis, chronic hepatitis, and normal liver. Int J Oncol 26: 661-671, 2005.

19. Bradford MM: A rapid and sensitive method for the quantitation of microgram quantities of protein utilizing the principle of protein-dye binding. Anal Biochem 72: 248-254, 1976.

20. Towbin H, Staehelin T and Gordon J: Electrophoretic transfer of proteins from polyacrylamide gels to nitrocellulose sheets: Procedure and some applications. Proc Natl Acad Sci USA 76: 4350-4354, 1979.

21. Workman P, Aboagye EO, Balkwill F, et al: Guidelines for welfare and use of animals in cancer research. Br J Cancer 102: $1555-1577,2010$.
22. D'Incalci M, Colombo T, Ubezio P, et al: The combination of yondelis and cisplatin is synergistic against human tumor xenografts. Eur J Cancer 39: 1920-1926, 2003.

23. Masaki T, Morishita A, Kurokohchi K and Kuriyama S: Multidisciplinary treatment of patients with hepatocellular carcinoma. Expert Rev Anticancer Ther 6: 1377-1384, 2006.

24. Liu B, Fan Z, Edgerton SM, Deng XS, Alimova IN, Lind SE and Thor AD: Metformin induces unique biological and molecular responses in triple negative breast cancer cells. Cell Cycle 8: 2031-2040, 2009.

25. Gong J, Morishita A, Kurokohchi K, et al: Use of protein array to investigate receptor tyrosine kinases activated in gastric cancer. Int J Oncol 36: 101-106, 2010.

26. Wang LW, Li ZS, Zou DW, Jin ZD, Gao J and Xu GM: Metformin induces apoptosis of pancreatic cancer cells. World J Gastroenterol 14: 7192-7198, 2008.

27. Verma A, Warner SL, Vankayalapati H, Bearss DJ and Sharma S: Targeting Axl and Mer kinases in cancer. Mol Cancer Ther 10: 1763-1773, 2011

28. Guttridge KL, Luft JC, Dawson TL, Kozlowska E, Mahajan NP, Varnum B and Earp HS: Mer receptor tyrosine kinase signaling: Prevention of apoptosis and alteration of cytoskeletal architecture without stimulation or proliferation. J Biol Chem 277: 24057-24066, 2002.

29. Sainaghi PP, Castello L, Bergamasco L, Galletti M, Bellosta P and Avanzi GC: Gas6 induces proliferation in prostate carcinoma cell lines expressing the axl receptor. J Cell Physiol 204: 36-44, 2005.

30. Li S and Hu GF: Angiogenin-mediated rRNA transcription in cancer and neurodegeneration. Int J Biochem Mol Biol 1: 26-35, 2010.

31. Hisai H, Kato J, Kobune M, et al: Increased expression of angiogenin in hepatocellular carcinoma in correlation with tumor vascularity. Clin Cancer Res 9: 4852-4859, 2003.

32. Boyerinas B, Park SM, Hau A, Murmann AE and Peter ME: The role of let-7 in cell differentiation and cancer. Endocr Relat Cancer 17: F19-F36, 2010.

33. Takamizawa J, Konishi H, Yanagisawa $\mathrm{K}$, et al: Reduced expression of the let-7 microRNAs in human lung cancers in association with shortened postoperative survival. Cancer Res 64: 3753-3756, 2004.

34. Yu F, Yao H, Zhu P, et al: Let-7 regulates self renewal and tumorigenicity of breast cancer cells. Cell 131: 1109-1123, 2007.

35. Akao Y, Nakagawa Y and Naoe T: Let-7 microRNA functions as a potential growth suppressor in human colon cancer cells. Biol Pharm Bull 29: 903-906, 2006.

36. Fu TY, Chang CC, Lin CT, Lai CH, Peng SY, Ko YJ and Tang PC: Let-7b-mediated suppression of basigin expression and metastasis in mouse melanoma cells. Exp Cell Res 317: 445-451, 2011.

37. Zhu XM, Wu LJ, Xu J, Yang R and Wu FS: Let-7c microRNA expression and clinical significance in hepatocellular carcinoma. J Int Med Res 39: 2323-2329, 2011.

38. Johnson SM, Grosshans H, Shingara J, et al: RAS is regulated by the let-7 microRNA family. Cell 120: 635-647, 2005.

39. Lee YS and Dutta A: The tumor suppressor microRNA let-7 represses the HMGA2 oncogene. Genes Dev 21: 1025-1030, 2007.

40. Osada H and Takahashi T: Let-7 and miR-17-92: Small-sized major players in lung cancer development. Cancer Sci 102: 9-17, 2011.

41. Haybaeck J, Zeller N and Heikenwalder M: The parallel universe: MicroRNAs and their role in chronic hepatitis, liver tissue damage and hepatocarcinogenesis. Swiss Med Wkly 141: w13287, 2011.

42. Borel F, Konstantinova P and Jansen PL: Diagnostic and therapeutic potential of miRNA signatures in patients with hepatocellular carcinoma. J Hepatol 56: 1371-1383, 2012. 